\title{
MENTAL HEALTH IN THE CONSTRUCTION INDUSTRY: A RAPID REVIEW
}

\author{
David Oswald ${ }^{1}$, Jessica Borg ${ }^{1}$, and Fred Sherratt ${ }^{2}$
}

\begin{abstract}
Principles of lean construction have been suggested as strategies towards improving health and safety $(H \& S)$ in construction. Previous research has typically focused on the physical aspects of $\mathrm{H} \& \mathrm{~S}$; yet individuals who work within the construction industry have an increased risk of suffering from mental health conditions. This is an area which is gaining attention but is yet to be researched in depth. Through a rapid review of literature, this paper identifies 15 studies, and reviews the current literature concerning mental health within the construction industry. Theoretically, results suggest that mental health is a significant problem within the construction industry; and practically, it is recommended that organisations should consider evidence-based suggestions of ways to address this issue through approaches such as alternate work schedules, and the use of validated detection tools. The results of the review revealed that the current literature is limited, both in terms of quantity and research approaches adopted, and therefore, further high-quality studies are required in this area. The principles of lean construction present an opportunity for addressing the issue of poor mental health in the construction industry, thus expanding the application of lean construction beyond addressing merely the physical aspects of H\&S issues.
\end{abstract}

\section{KEYWORDS}

Lean construction; waste; safety, quality, health; employee well-being; mental health

\section{INTRODUCTION}

Lean construction is a concept suggested for mitigating construction health and safety (H\&S) problems (Forman, 2013). The principles of lean construction have been used to promote physical health and safety as a way of improving productivity and minimising costs on construction projects (Bashir et al., 2011). Yet the application of lean construction to H\&S has typically focused on the physical aspects of H\&S, such as accidents; rather than the potentially less visible aspects, such as negative impacts on mental health. The consequences of poor mental health can be substanstial. For instance, a report in the UK found it was the leading cause of sickness absence, accounting for 70 million sick days in

1 RMIT University, 360 Swanston Street, Melbourne, Australia, 3001

2 Anglia Ruskin University, Chelmsford Campus, Chelmsford, UK, CB12LZ 
a year (Davies, 2013). The costs associated with mental health problems are staggering, with an estimated 25 billion forgone in gross value added to the UK economy in losses through absence, turnover and productivity (Unum, 2016). The construction industry is an environment that can be particularly at risk to poor mental health (Sherratt et al., 2018; Lingard \& Turner, 2015), and losses associated with mental health problems, such as absenteeism, can have direct implications for lean construction principles. This paper aims to review the current understanding on mental health and wellbeing within the construction industry, and consider the application of lean principles within this area. This research takes the form of a rapid review of the contemporary literature concerning mental health within the construction industry, thus taking a crucial first step in understanding the theoretical and practical implications of mental health and well-being within the industry's workforce and the potential for lean to enhance future developments.

\section{MENTAL HEALTH IN CONSTRUCTION}

Mental health conditions are significant in their impact on individuals, as well as their families, respective organisations and communities in which they work and live. The Health and Safety Executive (n.d) in the UK noted that one in four people will have a mental health problem at some point. Business leaders are becoming more aware of the productivity-related costs which poor mental health can cause through employee absences and wasteful on-the-job productivity practices (Goetzel et al., 2004). One of the main pillars of lean construction is waste reduction. While this has previously been associated with material wastage amongst construction personnel (Alarcon, 2014), contemporary lean principles are seeking to look beyond this to other forms of wastage. Hence, wastage should be viewed more broadly, and also encompass opportunity costs (Alarcon, 2014). A mentally unwell workforce is an opportunity cost, as high stress and burnout levels will likely reduce efficiency and productivity. Lean construction approaches have targeted reducing costs in the workplace (see, for example, Zimina et al., 2012), yet cost-saving through mental health promotion and prevention has arguably not received the attention it deserves. Previous work has highlighted that there is also a clear business case for implementing positive mental health strategies and preventing mental illness in workplaces, with mental health costs in the United Kingdom estimated at over $£ 100$ billion every year (Knapp et al., 2011).

The construction industry is particularly vulnerable to mental health issues, as the environment contains many occupational stressors such as: high production pressures, dangerous work, complex decision-making and 'not feeling tough enough', all of which can contribute to poor mental health (Sherratt, 2018). The way work is structured through long supply chains involving transient work, insecure temporary contracts, and long working hours also creates mental health risks specific to the industry (Sherratt \& Turner 2018). Perhaps unsurprisingly, research focusing on construction shows that its workforce is particularly at risk of poor mental health (Gullestrup et al. 2011; Milner et al. 2014; Roberts et al. 2013). Research (Meltzer et al. 2008; Milner et al. 2013) is consistent in showing that male construction workers have a higher rate of suicide when compared to 
males in other occupations; and Borsting Jacobsen et al. (2013) revealed that the incidence of mental distress in construction workers is double that of the level of the general male population. This has prompted workplace-based suicide prevention through intervention programs, such as Mates in Construction (see Gullestrup, et al., 2011). Workers have also identified that there is a need to create a work environment which is supportive of healthy behaviour (Lingard \& Turner, 2015), yet relatively little research concerning mental health in construction has been conducted. With the construction industry representing such a large portion of the global workforce, the mental health of construction employees arguably warrants critical attention.

\section{RESEARCH METHOD}

While there is no universal definition of a rapid review, it has been described as 'a type of knowledge synthesis in which components of the systematic review process are simplified or omitted to produce information in a short period of time' (Khangura, 2012:8). When there is a lack of relevant research, rapid reviews are often useful for aiding decisionmaking (Haby et al., 2016). While physical H\&S in the construction industry has been studied for many decades, research within the mental health and well-being space is much less prominent. Hence, a rapid review is considered appropriate for capturing the little research that has been conducted to date. The rapid review was conducted as per the following steps:

- Forming the research question/aim;

- Defining parameters and identification of biases;

- Consultation with a librarian for database selection;

- Screening, selection and application of a quality framework; and,

- Discussion of papers selected through the process.

The parameters for inclusion and exclusion criteria were based on journal quality, as defined by Scimago Institution rankings. This indicator accounts for both the quantity of journal citations, and the prestige of the journals where such citations emerge. The top quartile (Q1) and second quartile (Q2) journals were selected as appropriate for screening journal quality. The bias risks associated with only one reviewer undertaking this process were reduced, by having an additional reviewer also undertaking the screening, and application of the quality framework in the later steps of the review. Other bias that are worth noting include, i) the exclusion of grey literature, meaning there is a risk of missing unpublished literature, and ii) only studies in English were captured, risking missing literature in other languages. In terms of exclusion criteria, it is important to note that physical health studies were excluded, as were multi-disciplinary studies on mental health that had no findings specific to the construction industry. Furthermore, only studies conducted later than the year 1999 were selected, to ensure relevance and applicability to present day. 
An experienced librarian's advice for which databases would be most appropriate was sought. Eight relevant databases were highlighted, two of which, ICONDA and Science Direct (Elsevier) were deemed most suitable for the study. Key words in the multidisciplinary Science Direct (Elsevier) included: construction wellbeing, construction well-being, construction mental health, construction stress, and construction psychosocial. In ICONDA, an international construction database, searches included: wellbeing, wellbeing, mental health, workplace stress, and psychosocial. The results section illustrates the papers identified and selected for this research.

\section{SUMMARY OF FINDINGS}

Fifteen studies that met the criteria were conducted between the years 2005-2018, and of these, 10 studies were conducted over the last 5 years (see table below). Studies investigated the mental health of construction workers (blue collar) and construction professionals (white collar). The studies primarily focused on the negative aspects of mental health; these included stigma, psychosocial risk factors, stress and burnout. However, a couple of studies also investigating ways to improve, such as exploring appropriate work-life balances and ideas for the promotion of health and wellbeing.

Table 1: Overview of the 15 relevant studies in the rapid review

\begin{tabular}{|c|c|c|c|c|c|}
\hline Participants & $\begin{array}{l}\text { Country } \\
\text { of Study }\end{array}$ & $\begin{array}{l}\text { Author \& } \\
\text { Year }\end{array}$ & $\begin{array}{l}\text { Journal/ } \\
\text { Quality }\end{array}$ & Approach reported & Results \\
\hline $\begin{array}{l}682 \text { male } \\
\text { construction } \\
\text { workers }\end{array}$ & Australia & $\begin{array}{l}\text { Milner et al. } \\
2018\end{array}$ & $\begin{array}{l}\text { SSM - } \\
\text { Population } \\
\text { Health (Q2) }\end{array}$ & $\begin{array}{l}\text { Survey intervention to } \\
\text { address self-stigma. }\end{array}$ & $\begin{array}{l}\text { Self-stigma was relatively } \\
\text { low, and intervention not } \\
\text { significant. }\end{array}$ \\
\hline $\begin{array}{l}11 \\
\text { construction } \\
\text { workers }\end{array}$ & USA & $\begin{array}{l}\text { Jebelli et al. } \\
2018\end{array}$ & $\begin{array}{l}\text { Automation in } \\
\text { Construction } \\
\text { (Q1) }\end{array}$ & $\begin{array}{l}\text { Electroencephalogram } \\
\text { signals to test for stress at } \\
\text { work. }\end{array}$ & $\begin{array}{l}\text { Can determine early } \\
\text { detection of workers' stress. }\end{array}$ \\
\hline $\begin{array}{l}879 \text { health } \\
\text { and safety } \\
\text { professionals }\end{array}$ & $\begin{array}{l}\text { Ireland \& } \\
\text { UK }\end{array}$ & $\begin{array}{l}\text { Leitão \& } \\
\text { Greiner, } \\
2017\end{array}$ & $\begin{array}{l}\text { Safety } \\
\text { Science (Q1) }\end{array}$ & $\begin{array}{l}\text { Survey of members from an } \\
\text { institution of occupational } \\
\text { health and safety }\end{array}$ & $\begin{array}{l}\text { The construction sector } \\
\text { needed improvement in } \\
\text { reducing psychosocial risk } \\
\text { factors. }\end{array}$ \\
\hline $\begin{array}{l}256 \\
\text { construction } \\
\text { project } \\
\text { managers }\end{array}$ & China & $\begin{array}{l}\text { Yang et al. } \\
2017\end{array}$ & $\begin{array}{l}\text { International } \\
\text { Journal of } \\
\text { Project } \\
\text { Management } \\
\text { (Q1) }\end{array}$ & $\begin{array}{l}\text { An job-specific burnout } \\
\text { scale was created }\end{array}$ & $\begin{array}{l}\text { Construction project } \\
\text { managers have high levels } \\
\text { of job burnout. }\end{array}$ \\
\hline
\end{tabular}




\begin{tabular}{|c|c|c|c|c|c|}
\hline $\begin{array}{l}80 \text { trades } \\
\text { workers }\end{array}$ & UK & $\begin{array}{l}\text { Eaves et al. } \\
2016\end{array}$ & $\begin{array}{l}\text { Applied } \\
\text { Ergonomics } \\
\text { (Q1) }\end{array}$ & $\begin{array}{l}\text { Interviews, Nordic } \\
\text { Musculoskeletal } \\
\text { Questionnaire and Work } \\
\text { Ability Index. }\end{array}$ & $\begin{array}{l}\text { Over } 250 \text { ideas for health } \\
\text { and wellbeing. }\end{array}$ \\
\hline $\begin{array}{l}216 \\
\text { construction } \\
\text { workers }\end{array}$ & China & $\begin{array}{l}\text { Jia et al. } \\
2016\end{array}$ & $\begin{array}{l}\text { Applied } \\
\text { Ergonomics } \\
\text { (Q1) }\end{array}$ & $\begin{array}{l}\text { A grounded theory } \\
\text { approach into heat stress } \\
\text { risks and the relationships }\end{array}$ & $\begin{array}{l}\text { Construction heat stress } \\
\text { risks were socially } \\
\text { constructed }\end{array}$ \\
\hline $\begin{array}{l}676 \\
\text { construction } \\
\text { professionals }\end{array}$ & $\begin{array}{l}\text { South } \\
\text { Africa }\end{array}$ & $\begin{array}{l}\text { Bowen et al. } \\
2014\end{array}$ & $\begin{array}{l}\text { International } \\
\text { Journal of } \\
\text { Project } \\
\text { Management } \\
\text { (Q1) }\end{array}$ & $\begin{array}{l}\text { Survey and factor analysis } \\
\text { of } 13 \text { factor relationships } \\
\text { with perceived stress. }\end{array}$ & $\begin{array}{l}\text { Existing occupational stress } \\
\text { theories were not } \\
\text { completely supported. }\end{array}$ \\
\hline $\begin{array}{l}1500 \\
\text { supervisors } \\
\text { and } \\
\text { bricklayers }\end{array}$ & Holland & $\begin{array}{l}\text { Boschman } \\
\text { et al. } 2013\end{array}$ & $\begin{array}{l}\text { Applied } \\
\text { Ergonomics } \\
\text { (Q1) }\end{array}$ & $\begin{array}{l}\text { Dutch Questionnaire on } \\
\text { work experience and } \\
\text { evaluation. }\end{array}$ & $\begin{array}{l}\text { Psychosocial risk factors } \\
\text { for bricklayers and } \\
\text { supervisors. }\end{array}$ \\
\hline $\begin{array}{l}289 \\
\text { construction } \\
\text { employees }\end{array}$ & Sweden & $\begin{array}{l}\text { Tholén et al. } \\
2013\end{array}$ & $\begin{array}{l}\text { Safety } \\
\text { Science (Q1) }\end{array}$ & $\begin{array}{l}\text { Questionnaires, and } \\
\text { modelling analysis. }\end{array}$ & $\begin{array}{l}\text { Supportive psychosocial } \\
\text { conditions influence } \\
\text { individual safety } \\
\text { perceptions. }\end{array}$ \\
\hline $\begin{array}{l}626 \\
\text { construction } \\
\text { professionals }\end{array}$ & $\begin{array}{l}\text { South } \\
\text { Africa }\end{array}$ & $\begin{array}{l}\text { Bowen et al. } \\
2013\end{array}$ & $\begin{array}{l}\text { Engineering, } \\
\text { Construction } \\
\text { and } \\
\text { Architectural } \\
\text { Management } \\
\text { (Q2) }\end{array}$ & $\begin{array}{l}\text { A survey was developed to } \\
\text { determine perceived } \\
\text { workplace stress and } \\
\text { examined various stressors. }\end{array}$ & $\begin{array}{l}\text { Harassment and } \\
\text { discrimination were } \\
\text { experienced by all surveyed } \\
\text { South African construction } \\
\text { professions. }\end{array}$ \\
\hline $\begin{array}{l}269 \text { architects, } \\
179 \text { quantity } \\
\text { surveyors, } \\
168 \text { civil } \\
\text { engineers, } 60 \\
\text { construction } \\
\text { project } \\
\text { managers }\end{array}$ & $\begin{array}{l}\text { South } \\
\text { Africa }\end{array}$ & $\begin{array}{l}\text { Bowen et al. } \\
2013 b\end{array}$ & $\begin{array}{l}\text { Journal of } \\
\text { Construction } \\
\text { Engineering } \\
\text { and } \\
\text { Management } \\
\text { (Q1) }\end{array}$ & $\begin{array}{l}\text { A survey determined } \\
\text { perceived workplace stress, } \\
\text { and the exent of job } \\
\text { demands and job control }\end{array}$ & $\begin{array}{l}\text { Most respondents have } \\
\text { high workplace stress } \\
\text { levels; and architects have } \\
\text { higher levels than } \\
\text { engineers. }\end{array}$ \\
\hline $\begin{array}{l}73 \\
\text { construction } \\
\text { workers }\end{array}$ & USA & $\begin{array}{l}\text { Omosefe et } \\
\text { al. } 2011\end{array}$ & $\begin{array}{l}\text { International } \\
\text { Journal of } \\
\text { Industrial } \\
\text { Ergonomics } \\
\text { (Q2) }\end{array}$ & $\begin{array}{l}\text { Survey investigated job } \\
\text { demands, envoironmental } \\
\text { and organizational stressors. }\end{array}$ & $\begin{array}{l}\text { Stressors that are non- } \\
\text { physical should be included } \\
\text { in injury risk models. }\end{array}$ \\
\hline
\end{tabular}




\begin{tabular}{|l|l|l|l|l|l|}
\hline $\begin{array}{l}449 \\
\text { construction } \\
\text { professionals }\end{array}$ & Australia & $\begin{array}{l}\text { Love et al. } \\
2011\end{array}$ & $\begin{array}{l}\text { Journal of } \\
\text { Construction } \\
\text { Engineering } \\
\text { and } \\
\text { Management } \\
\text { (Q1) }\end{array}$ & $\begin{array}{l}\text { Use of the International } \\
\text { Survey of Stress and Mental } \\
\text { Health Survey. }\end{array}$ & $\begin{array}{l}\text { On-site workers had higher } \\
\text { levels of self-stress than } \\
\text { consultants. }\end{array}$ \\
\hline $\begin{array}{l}23 \text { wages } \\
\text { employees, } \\
\text { and 19 } \\
\text { salaried } \\
\text { employees }\end{array}$ & Australia & $\begin{array}{l}\text { Lingard et } \\
\text { al. 2007 }\end{array}$ & $\begin{array}{l}\text { Journal of } \\
\text { Construction } \\
\text { Engineering } \\
\text { and } \\
\text { Management } \\
\text { (Q1) }\end{array}$ & $\begin{array}{l}\text { Questionnaire surveys to } \\
\text { on moving from a 6-day to } \\
\text { a 5-day week, and semi- } \\
\text { structured interviews. }\end{array}$ & $\begin{array}{l}\text { Alternative work schedules } \\
\text { could improve the work- } \\
\text { life balance of construction } \\
\text { employees }\end{array}$ \\
\hline $\begin{array}{l}100 \\
\text { Construction } \\
\text { project } \\
\text { managers }\end{array}$ & UK & $\begin{array}{l}\text { Love \& } \\
\text { Edwards, } \\
2005\end{array}$ & $\begin{array}{l}\text { Engineering, } \\
\text { Construction } \\
\text { and } \\
\text { Architectural } \\
\text { Management } \\
\text { (Q2) }\end{array}$ & $\begin{array}{l}\text { A questionnaire survey } \\
\text { containing valid and } \\
\text { reliable scales for job } \\
\text { demand, job control, social } \\
\text { support and psychological } \\
\text { well-being. }\end{array}$ & $\begin{array}{l}\text { A job strain model could } \\
\text { significantly predict } \\
\text { employees' psychological } \\
\text { wellbeing, with social } \\
\text { support having significant } \\
\text { main effects. }\end{array}$ \\
\end{tabular}

\section{DISCUSSION}

The results generated from the rapid review illustrated that the challenge of mental health within the construction industry is an area of growing research interest, with studies conducted across continents: including Australia $(n=3)$, America $(n=2)$, Africa $(n=3)$, Asia $(n=2)$, and Europe $(n=5)$. As the challenge of mental health issues for employees within the construction industry is felt globally, further research is warranted in the area. While the extant literature shows that blue-collar workers have an increased risk of mental health issues and suicide (Milner et al. 2013), it is worth noting that research has explored mental health for both white and blue-collar workers. White-collar workers refer to employees for whom a large portion of the work is office/administrative based; for the purposes of this research, white-collar workers are identified as project managers, architects, engineers, and other professionals within the industry. In comparison, blue-collar workers refer to employees whose work is mainly site based and involves manual labour; and therefore, this research identifies blue collar workers as construction labourers/workers from various construction trades. Out of the 15 studies identified, 6 (40\%) focused on a sample of bluecollar workers, $6(40 \%)$ focused on white-collar workers and $3(20 \%)$ focused on both white and blue-collar workers, indicating that the mental health challenge applies to both categories of workers within the industry.

There were no studies that directly aimed to quantify the costs of mental health issues in the construction industry, but many noted that mental health was a problem. For instance, Leitão \& Greiner (2017) highlighted there was a need for improvement; Yang et al. (2017) revealed construction project managers suffered from high levels of job burnout; and 
Bowen et al (2013b) found that most survey respondents experienced high levels of workplace stress. Employees that are highly stressed or suffering burnout will not be operating at high productivity levels, and will more likely be inefficient and wasteful. One of the main pillars in lean construction is the reduction of waste, with a reduction in physical $H \& S$ accidents and incidents being viewed as an example of waste reduction (Bajjou et al., 2017). The mental health issues highlighted in this review suggests that lean construction principles should also be applied to this branch of H\&S, with emphasis on the mental health and well being of the workforce.

The literature provided evidence for improving workplace mental health, such as alternate work schedules (Lingard et al., 2007); evidenced-based ideas for improvement (Eaves et al., 2016), and ways of early detection of stress (Jebelli et al. 2018). Further research studies are required to build upon this literature in order to advance extant knowledge into how construction mental health problems can be identified and managed to produce a healthier workforce that ultimately, will reduce construction costs. Previous work has found that specific lean strategies, including continuous improvement programmes, seem to have some positive effects on safety (Nahmens and Ikuma, 2009); and hence, it can be argued that the relationship between such lean strategies and mental health in construction, should also be investigated.

From a research methods perspective, with the exception of three studies (Jia et al., 2016; Eaves et al., 2016; Lingard et al., 2007), all studies adopted a quantitative-only approach. Indeed the majority of studies have focused on the assessment/testing of the mental health wellbeing of construction employees. This methodological hegemony may indicate limitations in the current body of research on mental health in the construction industry, both in terms of quantity, given the limited samples identified in through the rapid review, as well as breadth of research investigations/approaches adopted in its examination. In the field of construction safety, Zou et al. (2014) highlighted that there could be a misalignment between the research studies that have been undertaken and the industry's practical needs. Oswald et al. (2018) also argued that approaches needed to go beyond the dominant paradigms, which attempt to prove and measure, typically through questionnaires, and instead to initate methodologies that reveal more exploratory insights. Such findings are likely to be limited and lack the richness of data able to inform and support the development of practical and effective interventions in practice. This rapid review found a dominance of quantitative methods, rooted in positivist traditions; and therefore makes a call for the mobilisations of other research methodologies, which can arguably be extended from physical safety, to also include mental health in the construction industry.

\section{CONCLUSION}

Lean construction principles have been suggested as strategies for improving physical health and safety in the construction industry. In studies focusing on health and safety within the industry, the mental health of the construction industry workforce has received 
less attention, despite being identified as a key contributor to escalating costs globally. Such costs can be viewed as resulting in wastage, which is one of the main pillars of lean construction. This review has identified that while studies have highlighted mental health as a problem within the construction industry, few studies have suggested ways to improve and address the global issue. Theoretically, the results of this study highlight that further research in this area is required in order to help fill this gap; and practically, this research suggests that organisations should consider evidence-based suggestions of ways to improve (such as alternate work schedules), and the use of validated detection tools (such as the use of electroencephalogram signals), to identify early signs of stress and mental health issues in both their white-collar and blue-collar employees.

This review illustrated that there are methodological limitations in the literature exploring mental health in the construction industry to date; and this research suggested that lean construction principles can be applied to the context of the mental health problem within the construction industry. Despite mental health in construction gaining increased attention, studies into the topic are limited and have adopted similar research approaches. Mental health within the construction industry is a global issue, that affects both blue and white-collar construction workers, and from a lean construction perspective, is one that currently represents an opportunity cost. In terms of limitations of this research, the rapid review study was limited to two databases capturing high-quality journal outputs and therefore is limited in size and scope. As mental health literature continues to grow, it is recommended that a systematic literature review is undertaken for future work.

\section{REFERENCES}

Alarcon, L., (2014) Training field personnel to identify waste and improvements in construction, In: Alarcon, L (Ed), Lean Construction, Taylor \& Francis: London

Bashir, A. M., Suresh, S., Proverbs, D. and Gameson, R. (2011) A critical, theoretical, review of the impacts of lean construction tools in reducing accidents on construction sites In: Egbu, C. and Lou, E.C.W. (Eds.) Procs 27th Annual ARCOM Conference, 5-7 September 2011, Bristol, UK, Association of Researchers in Construction Management, 249-258

Borsting Jacobsen, H., Caban-Martinez, A., Onyebeke, L., Sorensen, G., Dennerlein, J.T. \& Endresen Reme, S. (2013). Construction workers struggle with a high prevalence of mental distress and this is associated with their pain and injuries. Journal of Occupational and Environmental Medicine, 55(10), 1197-204.

Boschman, J., van der Molena, H., Sluitera, J., Frings-Dresena, M. (2013). Psychosocial work environment and mental health among construction workers, Applied Ergonomics, 44 (5), 748-755

Bowen, P., Edwards, P., Lingard, H. \& Cattell, K. (2014). Occupational stress and job demand, control and support factors among construction project consultants, International Journal of Project Management, Volume 32, Issue 7, October 2014, Pages 1273-1284 
Bowen, P., Edwards, P., Lingard, H. (2013). Workplace stress among construction professionals in South Africa: The role of harassment and discrimination, Engineering, Construction and Architectural Management, 20(6), 620-635.

Bajjou, M., Chafi, A., \& En-Nadi, A. (2017) The Potential Effectiveness of Lean Construction Tools in Promoting Safety on Construction Sites", International Journal of Engineering Research in Africa, Vol. 33, pp. 179-193

Davies, S. (2013) Chief Medical Officer's summary, Annual report of the Chief Medical Officer, Public Mental Health Priorities: Investiging in the evidence

Eaves, S. Gyi, D., \& Gibb, A. (2016). Building healthy construction workers: Their views on health, wellbeing and better workplace design, Applied Ergonomics, 54 (May 2016), $10-18$.

Forman, M. (2013) Inertia and change: lean construction and health and safety work on construction sites, Construction Management and Economics, 31:6, 647-660

Goetzel, R.Z. Long S.R., Ozminkowski R.J., Hawkins K., Wang S.H., Lynch W., (2004) Health, absence, disability, and presenteeism cost estimates of certain physical and mental health conditions affecting US employers, Journal of Occupational Environmental Medicine. 46:398-412.

Gullestrup, J., Lequertier, B. and Martin, G. (2011). MATES in Construction: Impact of a Multimodal, Community-Based Program for Suicide Prevention in the Construction Industry, Int. J. Environ. Res. Public Health 2011, 8(11), 4180-4196

Haby, M., Chapman, E., Clark, R., Barreto, J., Reveiz, L. \& Lavis, J. (2016). What are the best methodologies for rapid reviews of the research evidence for evidence-informed decision making in health policy and practice: a rapid review, Health Research Policy and Systems, 14-83.

HSE (n.d.) Mental health conditions, work and the workplace, Health \& Safety Executive, accessed 24/04/2019, available at: http://www.hse.gov.uk/stress/mental-health.htm

Jebelli, H., Hwang, S. \& Lee, S. (2018). EEG-based workers' stress recognition at construction sites, Automation in Construction, 93(Sept 2018), 315-324.

Jia, A., Rowlinson, S. \& Ciccarelli, M. (2016). Climatic and psychosocial risks of heat illness incidents on construction site, Applied Ergonomics, 53(March 2016), 25-35.

Khangura S, Konnyu K, Cushman R, Grimshaw J, Moher D (2012). Evidence summaries: the evolution of a rapid review approach. Syst Rev. 2012 Feb 10; 1-10.

Knapp, M., McDaid, D., and Parsonage, M. (2011) Mental health promotion and mental illness prevention: the economic case.

Leitão, S. \& Greiner, B. (2017). Psychosocial, Health Promotion and Safety Culture management - Are Health and Safety Practitioners involved? Safety Science, 91 (Jan 2017), 84-92

Lingard, H., Brown, K., Bradley, L., Bailey, C. (2007). Improving Employees’ Work-Life Balance in the Construction Industry: Project Alliance Case Study, Journal of Construction Engineering and Management, 133(10), 807-815.

Lingard, H. \& Turner, M. (2015). Improving the health of male, blue collar construction workers: a social ecological perspective, Construction Management \& Economics, $33(1), 18-34$. 
Love, P. \& Edwards, D. (2005). Taking the pulse of UK construction project managers' health: Influence of job demands, job control and social support on psychological wellbeing, Engineering, Construction and Architectural Management, 12(1,.88-101.

Love, P., Edwards, D. \& Irani, Z. (2010). Work Stress, Support, and Mental Health in Construction, Journal of Construction, Engineering and Management, 136(6),650-658

Meltzer, H., Griffiths, C., Brock, A., Rooney, C. and Jenkins, R. (2008). Patterns of suicide by occupation in England and Wales: 2001-2005. British Journal of Psychiatry, 193(1), 73-6.

Milner, A., Spittal, M., Pirkis, J. \& Lamontagne, A. (2013). Suicide by occupation: Systematic review and meta-analysis. British Journal of Psychiatry, 203, 409-16.

Milner, A., Niven, H. \& Lamontagne, A.D. (2014). Suicide by occupational skill level in the Australian construction industry: Data from a national register of deaths over the period 2001 to 2010. Australian and New Zealand Journal of Public Health, 38, 281285

Milner, Law, P. Mann, C. Cooper, T., Witt, K., LaMontagne, A. (2018). A smart-phone intervention to address mental health stigma in the construction industry: A two-arm randomised controlled trial, SSM - Population Health, 4(April 2018), 164-168.

Nahmens, I. and Ikuma, L.H. (2009) An empirical examination of the relationship between lean construction and safety in the industrialized housing industry. Lean Construction Journal, 1-12.

Omosefe A., Harvey, C., Ikuma, L., \& Aghazadeh, F. (2011). Modelling the relationship between occupational stressors, psychosocial/physical symptoms and injuries in the construction industry, International Journal of Industrial Ergonomics, 41(2), 106-117.

Oswald, D., Sherratt, F., Smith, S., and Dainty, A. (2018) An exploration into the implications of the 'compensation culture' on construction safety, Safety Science, 109, 294-302

Roberts, S.E., Jaremin, B. \& Lloyd, K. (2013). High-risk occupations for suicide. Psychological Medicine, 43, 1231-40.

Sherratt, F. (2018) Shaping the discourse of worker health in the UK construction industry, Construction Management and Economics, 36 (3)141-152.

Sherratt, F. and Turner, M. (2018) Exploring the hidden social consequences of working in construction with Q Methodology: Developing a study for Australia and the UK, Proceedings of the CIB W099 and TG59 Conference, Salvador, Brazil, 1-3 August 2018.

Tholén, S., Pousette, A. \& Törner, M. (2013). Causal relations between psychosocial conditions, safety climate and safety behaviour - A multi-level investigation, Safety Science, Volume 55 (June 2013), 62-69.

Unum (2016), Added Value: Mental Health as a Workplace Asset, Mental health foundation

Zimina, D., Ballard, G., \& Pasquire, C. (2012) Target value design: using collaboration and a lean approach to reduce construction cost, Construction Management and Economics, 30:5, 383-398

Zou, P.X.W. Sunindijo, R.Y. \& Dainty, A.R.J. (2014), A mixed methods research design for bridging the gap between research and practice in construction safety, Safety Science, 70, pp. 316-326 